\title{
The Interdisciplinary Possibilities of Literary and Visual Creation: The Case of Jurga Ivanauskaite
}

\author{
Jūratė Baranova \\ Department of Philosophy, Lithuanian University of Educational Sciences, \\ Ševčenkos 31-228, Vilnius, LT -03111 Lithuania \\ jurabara@gmail.com
}

Doi:10.5901/ajis.2015.v4n1s2p285

Abstract

This article deals with the phenomenon of Jurga Ivanauskaitè (1961-2007), considered to be one of the most interdisciplinary and poly-sided Lithuanian women writers and artists. As an artist, as well as a writer, she was impressed by the works of Hieronymus Bosch and Peter Bruegel, and modern surrealists works, such as those of Salvador Dali, Paul Delvaux, Giorgio de Chirico, and especially René Magritte. She felt a deep closeness with the Mexican painter Frida Kahlo. The main thesis of this study is that, mainly, the encounter with modern Western visual art allowed the writer to break the rules of the established limits of national Lithuanian literature and escape the closeness of the Soviet block mentality and create the new paradigm of "town literature", based on openness to the world and experimentation. Mainly, an interdisciplinary upbringing encouraged Ivanauskaite to search courageously for new modes of expression in literature and visual painting, as well as in her life style.

Keywords: Jurga Ivanauskaitè, interdisciplinary, surrealism, Lithuanian literature

\section{Why Jurga Ivanauskaite Can be Considered an Interdisciplinary Writer ?}

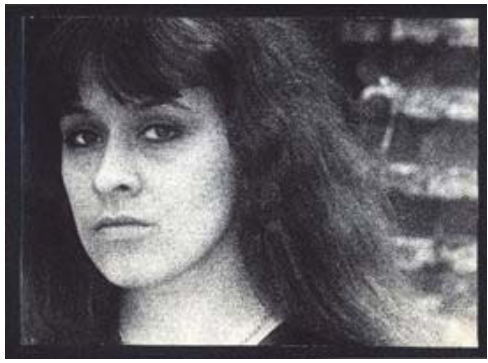

Jurga Ivanauskaitė was a prose write, poet, essayist, playwright and artist. She wrote twenty books: two collections of short stories Pakalnučiu metai (The Year of the Lilies of the Valley, 1985), Kaip užsiauginti baimę (How to Raise One's Own Fear,1989); seven novels: Ménulio vaikai (The Children of the Moon, 1988), Pragaro sodai (The Gardens of Hell,1992), Ragana ir lietus (The Witch and the Rain, 1993), Agnijos magija (Agnija's Magic,1995), Sapny nublokšti (Gone with the Dreams, 2000), Placebas (Placebo, 2003), Miegančiu drugeliu tvirtovè (The Fortress of Sleeping Butterflies, 2005); four personal essay collections Ištemtas Tibetas (Tibet in Exile, 1996), Kelionè i Šambala (The Journey to Shambhala, 1997), Prarasta pažadètoji žemè (The Lost Promised Land, 1999), Kelioniu alchemija (The Alchemy of Travels, 2003), two collections of poems Šokis dykumoje (The Dance in the Desert, 2004) and Odė džiaugsmui (Ode to Joy, 2007), a collection of interviews Švelnūs tardymai (The Gentle Interrogations, 2005), two books for the children Stebuklingojii spanguolè (The Miraculous Cranberry,1991) ir Kaip Marsis žemėje laimès ieškojo (How Marsas looked for the Happiness on Earth, 2004), diary Viršvalandžiai (Overtime, 2008, published post mortem), the collection of plays Nežaiskite su Mėnuliu (Don't Play with the Moon! 2008, published post mortem) and the book of meditation Angelo rūbas (The Angel's Dress, 2011, published post mortem). Also the collection of three former eesay books on her travels in India and Tibet was published as Tibeto mandala (The Tibetan Mandala, 2004). Her play Don't Play with the Moon!, in which she followed the principles of Antonin Artaud's theater of cruelty and Oscar Wilde's insights in his play Salome, was produced by the State (currently National) Drama Theatre in 1987. She also created the decorations for the stage. She had never fulfilled her dream of becoming a movie director and some of her first novels written as movie scripts where her beloved actors from Andrei Tarkovsky's movies were able to play. She also used to make photographs and is famous as 
a writer-traveller. In 1999 she gave an exhibition of photography show called Tibet - a Different reality. Her creativity and world perception were influenced not only by literary contexts (Jack Kerouac, Saulius Tomas Kondrotas, Ričardas Gavelis) but also by surreal art ( Hieronymus Bosch, Pieter Bruegel, Salvador Dali, Paul Delvaux, Giorgio de Chirico, Šarūnas Sauka and especially - René Magritte), classical art (El Greco, Mikalojus Konstantinas Čiurlionis old sacral painting and others), cinema (Luis Buñuel, Ingmar Bergman, Andrei Tarkovsky), theatre and music (John Lennon, Jim Morrison, Philip Glass, Arvo Pärt), philosophy (Albert Camus, Jean Paul Sartre) and other theoretical literature. The works of Mircea Eliade and Carl Jung formed Ivanauskaitè's interpretation of the relationship between the East and the West. Ivanauskaite also adopted some of Jung's principles of existential auto-therapy - she actually reiterated Jung's idea of drawing mandalas to restore spiritual harmony. She was also interested in the life and works of exceptional female mystics such as Hildegard of Bingen and Simone Weil. Jurga Ivanauskaite was one of the most intellectual Lithuanian writers of the twentieth century and of the turn of the twenty-first centuries. Her works have been translated into thirteen languages, including English (2002b, 2002c, 2004e, 2010, 2011b, 2013a), Latvian (1998, 1999b, 2000b, 2001a, 2006b, 2013b), Polish (2001b), Hungarian (1997c), Russian (2002f), Estonian (1997b), German (2002d, 2002e, 2005), Swedish (2005c), French (2003c), Croatian (2003e, 2004f, 2008), Czech (2006c), Italian (2010c, 2013c), and Slovenian (2014b).

On the other hand, she was also an artist. In 1980 she graduated from M.K.Čiurlionis Art School. In 1985 she completed her studies at Vilnius Art Academy, where she majored in graphic arts. When she graduated, she received the diploma of a poster artist, following in the footsteps of her father, a Russian scenery and poster artist in Leningrad (currently Saint-Petersburg), Igor Ivanov. As a teenager visiting Leningrad with her class, she became acquainted with her father's surrealist works. She illustrated her own books and some by other others. Ivanauskaitè's visual works as well as her literary creation from the early period are significantly influenced by surreal symbolism, in some cases - interwoven with Japanese art. The literary works are stylistically dominated by a playful witty surrealism reminiscent of René Magritte, while the literary text is constructed with the question 'what if?' in mind (The Year of the Lilies of the Valley). When she started to write literature she abandoned visual art. But ten years later when traveling in India Ivanauskaitè returns to visual art: she draws Mandalos, a cycle of 110 mandalas. She approaches this cycle by way of realizing their conceptual meaning, similarly to Jack Kerouac's character Japhy from the novel The Dharma Bums. Her actions follow Carl Jung's assumption of the mandala as a harmonizing auto-therapy. The cycle Mandalos is an example of Jung-esque surrealism in which the existential, especially death fears, experienced by the artist-writer are entwined with the pressure of a foreign culture and its deities, the reflections of Western surrealism, and her own creative wit.

Although Tibeto mirusiuju knyga (The Tibetan Book of the Dead, 2002), a cycle of nine paintings, was created upon when the artist-writer's return to Lithuania, on the mental level it still symbolizes the running of Tibetan imagery in her creative periphery. This cycle reveals the different planes of existence that were among the pillars of support to Ivanauskaitè's worldview.

During the post-Tibetan period, Ivanauskaite creates a cycle of unique visions, Angelariumas (The Angelarium, 2005), in which she reaffirms the idea of an ecumenical longing for sanctity that covers different faiths. Some of her angels have stepped from the pages of the Koran, others from the Kabbalah, still others were inspired by Biblical symbolism. They are gorgeous and playful, and at times it seems they were created in a light-hearted mood. They are unusually, almost cosmically, magnified in comparison to the small figures of young red-haired girl as possible painter's alter ego and animals below. Conversely, they are, in their own way, prophetic. The technique used in making them brings to mind the tradition of Easter palms, or verbos, of the Vilnius region. The angels are painted or glued together from dried flowers, leaves and blades of grass familiar to Ivanauskaitè. She said: "Regular colours don't suit angels. So I made them as collages of the many varieties of colours and 'fabrics' of herbs and flowers that I collected. I referred to the Kabala and read the Koran, and I realized that angels are the only entity that unites all religions" (Jarvis 2005:25). In some aspects of her world perception (her love for nature and animals, or her experiments in self-portraits) the writer's visual works can be compared to those of the Mexican painter Frida Kahlo.

In the book Jurgos Ivanauskaitès fenomenas: tarp siurrealizmo ir egzistencializmo (The Phenomenon of Jurga Ivanauskaitè: Between Surrealism and Existentialism), a textual comparison of the two creators of seemingly different parameters, those of Frida Kahlo and Jurga Ivanauskaitè, is made, keeping in mind that all such comparisons become powerless outside the text. The inspiration for this comparison came from the writer herself, who in the final stage of her life felt an existential affinity with the Mexican painter. This affinity Ivanauskaite herself might have called the phenomenon of 'synchronicity'. Ivanauskaitè's posthumously published diary, Overtime, can be seen as her response to the diary of Frida Kahlo that Ivanauskaite had ordered in Spanish. She hoped to one day read it in the original, but didn't have enough time left to learn the language. 
Why did the artist one day exchange the brush for the pen? Ivanauskaite recognized that she always felt a deep longing for literature: "My paintings until now have been very literary; I like to include into them not only a brief plot, but the entire narrative as well - the story, the heroes - in order to make them a bit similar to the animated cartoon films where everything is moving from point A to point Z, where it changes from the beginning to the end" (Baranova 2014: 193).

The Lithuanian painter Leonardas Gutauskas also made the switch from painting to literature. He reflected upon it by saying, "In a painting everything is simpler for the reason that when you painted the picture, it dies. You painted for example a tree and it would not be able to grow for thousands of years, nobody would cut it, nobody would feel it. And my angel (as I used to paint) had a raised sword that would not be let down for thousands of years. But literature is constantly boiling, moving, living, changing shapes. It is immortal. Not for the reason that literary work is good. It is in principle immortal all the time, as a geyser" (Baranova 2014: 193).

\section{Discussion of the Problem}

In the book presenting Baltic writers for English-speaking readers, it is stated that Ivanauskaite is "the most popular contemporary Lithuanian writer reflecting the approximation of 'high' and popular cultures in the post-modern world. Lithuanian literary criticism finds her controversial, as a discoverer of new paths, and as too popular an author. Apart from her literary work, she was also an outstanding personality in public life: a journalist, a public figure (the active member of the Lithuanian Tibet Support Group). During the last years of her life, she spoke openly about the struggle against cancer in a way that was rather unusual in Lithuania" (Daugirdaite 2009: 109). On the other hand her novel The Witch and the Rain (1993) was considered as rather rebellious because it opened up a new perspective on the exploration of feminine sexual passion. "Because of the novel's open eroticism and because Ivanauskaitè depicts a Catholic priest having sex with a young woman, the city council of Vilnius restricted the distribution of the book. The act only ensured its popularity. The novel was seen by some as offensive because it mocked religious and moral sensibilities in a country with a strong Roman Catholic tradition" (Jonušys 2002: 306). In spite of Ivanauskaitè's popularity among readers, she experienced a deep feeling of loneliness, the sense of being neglected by the critics and disdained by contemporary writers. "My writers - colleagues openly demonstrate hostility to me", she said in one of her interviews (Baranova 2014: 504). When she was ill and struggling for life, she went to have surgery in Sweden and was left with one lung and unable to move. The writer Renata Šerelytè, providing criticism of prose from 2005, when Ivanauskaitè's novel The Fortress of Sleeping Butterflies was also published, expressed the opinion that she did not understand how it was possible to write about Ivanauskaite's work at all. Ivanauskaite read this and wrote to her friend: "I suggest you to also buy the journal Metai and read about the prose of 2005. Especially the "piece" by Renata Šerelytè. We both are the enemies of the nation and literature and for this reason it is already time for us to leave for the cemetery" (Urbonaite 2015: 369).

Seven years after Ivanauskaitè's death, Gabrielè Gailiüté published results of an inquiry revealing that Ivanauskaite's prose received the most numerous attention from researchers as is recorded in The International Research Database "Lituanistika" (Gailiūtè 2014: 5). A number of Lithuanian literary critics wrote about her work from different points of view : V. Kubilius (1996, 1999, 2002), V. Daujotytè $(2001,2009,2001,2007)$, J. Sprindytè (2006), I. Gražytè-Maziliauskienè (2004), A. Peluritytè-Tikušienè (2001, 2003, 2003, 2003, 2006, 2006), V. Rubavičius (1979, 1997, 2007), E. Baliutytè (2003), A. Balbierius (1999, 2013), G. Beresnevičius (1999, 2000, 2003), J. Čerškutè (2009), V. Kelertienė (2004, 2006, 2006), G. Kazlauskaitè (2006, 2007), V. Juknaitė (2001, 2005, 2008), V. Jauniškis (1987), L. Jonušys (2013), G. Lučiūnienè (2005), J. Lukšytè $(2000, \quad 2000, \quad 2006, \quad 2006) \quad$ S. Daugirdaitè $(1993,1999,2000,2000,2002,2006)$, A. Danielius (1996), V. Martinkus (2003), K. Navakas (2008), I. Vedrickaitè (2006, 2010, 2010), R. Pociūtè $(2006,2009)$, R. Rudaitytè (2009), A. Ruseckaitè (2005), M. Kvietkauskas (2003), L. Tirvaitè $(1985,1987,1987,1989)$, A. Samalavičius (1988), R. Skeivys (2007), K. Urba (2003), etc. On Ivanauskaitè's prose also reflected philosophers: A. Andrijauskas (2004, 2007, 2007, 2010), G. Mažeikis (2012), A. Uždavinys (2002). Art critics V. Ryžovaitė (2005), R. Rachlevičiūtè $(2011,2012)$, K. Stančienè (2011), and J. Sereikaité (2011) also wrote about her visual creation. The famous poet $\mathrm{S}$. Geda from time to time mentioned her in his published diaries. Why was she so popular? L. Mačianskaitė notices: "J. Ivanauskaitè is called the most provocative Lithuanian writer; however, her innovations are not an end in itself: they are birthed from painful reactions to the poverty of social life and existential hopelessness (as in her collections The Year of the Lilies of the Valley (1985) and How to Raise One's Own Fear (1989). G. Radvilavičiūtè (the author of Planned Moments (2004), Tonight I Shall Sleep by the Wall (2010) and the winner of the EU Prize for Literature ), while writing a conceptual introduction to the International literary forum North Summer, twice returned to Ivanauskaite's work by noticing in it the expression of the creative imagination and revolt. G. Radvilavičiūtè 
writes: "Ivanauskaite <...> into the textile of the language weaved on equal rights the songs of Western groups, idyllic and a bit sentimental, the nostalgic, provincial, natural background she had changed into a dynamic, exotic and sinfully seducing town". Philosopher G. Mažeikis notices Ivanauskaitè's courage to balance herself near the limit and to intersect it, and by this to meet the breathing of the possible other world, the courage to open herself to the unknown (Mažeikis 2012: 46).

Ivanauskaite in 2005 received the highest literary award in Lithuania, the National Prize, for the openness of her creation to the world and for the cultural diversity in Mandala of Tibet (2004) and for the sensation of shifting values in her novels. The phenomenon of Ivanauskaite reveals a new lifestyle characterized by an openness to the world, but not to any specific culture, and the ability to respond to symbols of any culture, be they from the West (surreal art, rock music, modern literature by Rainer Maria Rilke, Franz Kafka, Thomas Mann, Herman Hesse and others), from the 'Near' East, or Russia (Fyodor Dostoyevsky, Aleksandr Blok, Joseph Brodsky, Anna Akhmatova, Marina Tsvetayeva and others), or from the Far East (Japanese engravings, Tibetan Buddhism, etc.), or from the 'third world' countries (Egypt, Peru). Ivanauskaitè's literary breakthrough was writing cosmopolitan literature for both adults in The Tibetan Mandala trilogy, in novel Gone with the Dreams and essay book The Alchemy of Travels and also for children in the book How Marsis Searched for Happiness on Earth.

The presumption of our investigation is the following: the features of Ivanauskaite's literary creation can be understood only by taking into account the interdisciplinary mode of her creativity and her openness to visual culture. Her creation oversteps the distinction "popular or elite" and cannot been reduced to any simple formula. Her works are based on a permanent search for a new creative code. Each book is different from the previous one. Nevertheless, it is possible to distinguish in her works some repeating signs.

\section{Surreal and Existential Signs in Pre-Tibetan Creation}

'A writer isn't a writer man; he is a machine-man, and an experimental man <... >'(Deleuze, Guattari 1986: 7), wrote Gilles Deleuze and Felix Guattari in their book Kafka: Pour une Littérature Mineure (Kafka: Toward a Minor Literature). In both literature and life a writer produces signs. This study aims to decipher and interpret the signs created by Jurga Ivanauskaite. The signs that were found are classified as surreal or existential. Surreal signs in her creation are expressed in the paradigms of dream, ecstasies, impossible reality, redoubleness, alternative realities. Existential signs reveal themselves as loneliness, fear, estrangement, death, journey, love until death (meiliamirystè), suffering, passion for life and the feeling of numinosum. These signs are not created by her, but deciphered. As it was asked and answered by Deleuze: "Why has Masoch given his name to a perversion as old as the world? Not because he "suffered" from it, but because he transformed the symptoms" (Deleuze 1995; 143). The symptom of masochism always existed but was unnamed; Masoch just made his diagnosis in his fiction. "Masoch's a great symptomatologist", concludes Deleuze (Deleuze 1995: 142).

In the same manner Ivanauskaite diagnoses the sources of existential anxiety by giving them literary and visual form. A sense of existential apocalyptic fear, first perceived in the novella The Year of the Lilies of the Valley, becomes prominent in the author's second collection of short stories How to Raise One's Own Fear. Ivanauskaitè decrypts a wide array of possible signs of fear. The apocalyptic atmosphere is connected to the various unexpected possibilities of an overturned reality: a liquid from the sea sets organic creatures on fire, a red dress sticks to the body and melts it. Like in Sartre's novel La Nausée (Nausea), the dread of a spontaneous change in the world (being in itself, en soi) can be felt (as Sartre wrote, 'it is out of laziness that the world is the same day after day').

Ivanauskaite grew up in a family with literary traditions. Her grandfather Kostas Korsakas was the director of the Literary Institute of the Lithuanian Academy of Science during the Soviet period and her grandmother Halina NastopkaiteKorsakiene wrote reminiscences and short stories. Her mother was an art critique and Ivanauskaitè was expected to become an artist as her father. But unexpectedly in 1982 she started to publish her novels and in 1985 her first book, The Year of the Lilies of the Valley, appeared full of surreal signs of impossible, double and alternative realities. In the short story of the same title as the book The Year of the Lilies of the Valley, a group of young people is traveling to Pskov and decide to rest in the field of the lilies of the valley as if they were 'flower children". Pskov was the old Russian town where some esoteric religious experience was practiced in orthodox churches and where some Lithuanian youth searching for an alternative experience used to make pilgrimages to. The young characters in Ivanauskaite's story discussed spiritual forces, spirit games and Kant's categorical imperative, Japanese art, the music of Bach, the painting of Chagall, incarnations of Buddha, and Santayana's conception. Suddenly on the road they saw a funeral procession. After visiting Pskov they rested in the suburbs of the town. While they were sleeping, the main narrator noticed: "Suddenly a sharp 
pain pierced my right hand. I opened my eyes and lifted my head. I was surrounded by nothing else but lilies of the valley. Again, I felt a pain in my right palm. I looked and I was horrified to see two seedlings rising from my hand. Shocked, I jumped to my feet - my friends were bursting with the lilies of the valley. It was as though they were nailed to the floor by delicate, tinkling stems: they couldn't move" (Ivanauskaite 2013a: 156). The unexpectedness of the plot in these short stories, like a surreal upturn of reality, is very close to Magritte's thought experiments in his painting. Belgian surrealist René Magritte (1898-1967) encouraged creativity of philosophical thought in his painting. Magritte proposed an "optimistic" version of surrealism, based not on the unconsciousness or dreams but on the unexpected overturning of reality. His paintings are examples of the plausible inversions of formal logic and ordinary meaning, leading in each case to a paradox. In the short story When will Godot Come? (Ivanauskaitè's first story from this collection), characters from Samuel Beckett's play Waiting for Godot meet with Magritte's character - the man with the black coat and hat. The young writer asks a provocative question: What if Godot came at last? What would he be like? Possibly as a character from Magritte's paintings. The paradoxical intrigue of Ivanauskaitè's short stories is based on the interweaving of surreal signs from painting and from literature. The story The Day That Never Happened is also based on a rather "Magrittian" question: "What if New Year's Day never came?" formulated in the very beginning of the plot: "Just look at the calendar and you'll see for yourselves. That day simply did not exist!" (Ivanauskaite 1997d: 193). The story is recalled from a young man's perspective. In the day that never came he met the girl who made him sick with her talks about supreme love. He hated her and scolded her naiveté and left the room but when he returned he found her in blood and disaster. The room was full of feathers. The fragile creature moaning in his bed appeared to have wings and feathers. The narrator glanced at his own hands and noticed that tangled feathers and iridescent dust clung to his blood-covered hands and arms. "I broke her wings <...> sooner or later someone would have done it", concluded the narrator (Ivanauskaite 1997: 201). The writer in this story turned upside down the expression 'to break the wings', transferring it from language into reality. The question "What if our words unexpectedly turned into real events?" is also very close to Magritte's thought experiments.

Ivanauskaitè's literary work also has a social-historical meaning as in the novel The Children of the Moon (1988) she reconstructs the consciousness and lifestyle of certain subcultures (punks, hipsters) of the Lithuanian youth in the 1990s. The writer's choice to include diverse areas of culture into her erudition-enhancing works bears witness to the formation of an unofficial alternative system of self-education among a certain group of young people in the second half of the twentieth century which was not drawn from the contents of official Soviet institutional programs.

The study reveals certain creative parallels between the works of Jack Kerouac, the inspiration behind the beatnik movement, and Ivanauskaite. The most prominent of these are the interpretation of the phenomenon of travel as a search for God, and turning towards Eastern Buddhism (see The Dharma Bums by Kerouac). Unlike Kerouac, who only studied Buddhism in the library, Ivanauskaite turned this interest to an existential level: she started to travel herself searching for Buddhism in India and Tibet.

In the novel The Children of the Moon, the surreal symbols lose their apocalyptic power. The author returns to reality and examines the alienation of urban youth through the lifestyle of the punk and hipster generation. Communication is dominated by monologues; the characters are defined by a search for ecstatic experiences, balancing on the edge of madness, self-destruction, educating oneself in music, and a nomadic lifestyle. As noticed Vytautas Kubilius, "Ivanauskaite is the only one Lithuanian writer who experienced stronger influence of the hippie movement, which had reached the Baltic countries in the 1960s. Heroes of her novellas, drama and the first novel The Children of the Moon (1988) wear their hair in combs, play noisy rock music ("Music was flaying in the room like ball lightning"), inject "intoxicating solution" in their veins, are proud to be "schizophrenic". They gather in the same cafes in Castle street, but do not feel above the aura of the past and culture of Vilnius. "our generation is the generation of cosmopolitans, and I do not consider it a disaster", says one of the heroes of The Children of the Moon. They adore the Beatles and Kerouac, read the Kamasutra, The Tibetan Book of the Dead, Seneca, sometimes Mačernis. But they do not believe in anything. They feel a vicious destructive power hiding in the core of the world which is woken by somebody's strong biological field (in a museum butterflies set themselves free from stands, break the display cases and fly around). Black, scorching, invisible waves, independent of will and consciousness, are moving among people. Heroes of the novel, depressed by universal dissonance ("I feel so bad"), bang their hands against a wall, wishing to crumble into "tiny tiny pieces". The world is irrepressibly falling into an abyss - nuclear death, and we will go off in a moment. Fear of self-destruction ("We are half a kilometre away from the epicentre of explosion") undermines any will to arrange one's life, which will end in a minute" (Kubilius 1997: 503). The heroes from the The Children of the Moon are listening to The Beatles or The Doors music, talking about Mikalojus K. Čiurlionis and Salvador Dali art. Ivanauskaitè, in a personal essay written during her travels in India, returns to Dali's ideas about reincarnation. Some episodes of the dreams in Ivanauskaite's early novels 
could be seen as a pictures painted in the style of Salvador Dali. The girl from the novel The Children of the Moon narrates the dream she has every night: she is running as quickly as possible, breaking a dazzling red rush and strikes against her beloved. In the continuing action remains the picture of Salvador Dali, as if it started to move and become a movie: she is slipping from the hands of her beloved, turning into some liquid as transparent as water. "Afterwards everything is poured over by yellow; I disappeared, and the huge dark green bird with shining eyes is landing on your heard. Your body from his weight or stroke started to split; from the top of the heard all your body is cracking and starts to crumble into small shivers, flying in all directions as if by a sling of centrifugal force, without sound, with the yellow shining in gloomy twilight (Ivanauskaitè 2004: 135). Gintautas Mažeikis notices that at the end of the Soviet period the surrealism and figure of Dali appeared as a manifestation of the psychological liberation for alternative youth (Mažeikis 2012:60).

The novel The Gardens of Hell (1992) was written between 1989 and 1990, at the time of the collapse of the Soviet system, and was published after the re-establishment of independence. It is a novel of the junction of two eras. Conversely, the novel points to the alienation of members of subcultures as an aspect of historic reality and their inability to find their spiritual bearings in the new reality. Furthermore, a new creative element is introduced as Ivanauskaite brings the metaphysical collision of good and evil into the literate space. Domantas, the main character, immolates himself believing that he represents the dark forces of the Antichrist and hell. The writer's preference for fire as a means of selfdestruction becomes more pronounced. Having adopted the binding approach of feminist literature to speak openly "about the most intimate things in life", in her novel The Gardens of Hell Ivanauskaite described the outbursts of woman's passion, losing senses over a man's scent, trembling body, emotional ecstasy while making love in a messy hotel or even in the WC or in flying aircraft. Raging, losing one's mind, being sexual - this is the calling of a modern woman, who freed herself of the bonds of Puritanism. Only love and death exist to rock stars. There are no more essential values which could fill the abyss between these two elements of existence. Heroes of the novel experience the feast of spiritual revival, pasting posters inviting to the first meeting of Sajūdis, however the feast is short. As soon as a handsome singer urns away from one of his four girl-friends, she decides, "Everything's finished"., "I want to die". Even in bed with another man and whispering the name of the beloved who deserted her, she wished to destroy herself and vanish irrevocably. As noticed Kubilius, "Ivanauskaitè's narrative is easy - flowing and impulsive, branching off into dialogue parts - confessions of lovers, like in Kunčinas' novels. Her word, however, is not so open to the attributes of the outward reality and phraseology of the spoken language. It focuses on inner self-observation, lingers in the space of psychological, philosophical and cultural notions, foreboding that threatening demonic powers are hiding on the other side of visible shapes. Having distributes points of view and the rights of narration to a number of characters, the novelist constructively twists the stories of their lives into a integral compositional ball, maintaining the atmosphere of emotional feeling or even inner identity. Hippie-like emotional exaltations, aesthetized neuroses, psychoses of self-destruction of the characters are pushing their way the scales of the highest tension, and Ivanauskaite is made to theatricalize the plot situation (incurable cancer, a suicide), to turn to fairly sentimental representation " (Kubilius 1997: 504-555).

The novel The Witch and the Rain, (1993) brought the author international acclaim. It is translated and published into Latvian (1994, 2013b), Russian (1995), Estonian (1997b), German (2002d, 2004), Croatian (2003e), Swedish (2005c), Czech (2006c), Italian (2013c), Slovenian (2014) languages. The novel has a contemporary point of departure, but it also flashes back hundred of years to stories old by medieval witch (personage M.V.) and by Mary Magdalene. The various aspects of a wild, bewitching, disastrous woman's love have a persuasive intensity, expressed in an accomplished literary text. An innovative linkage of time dimensions, removed from each other by centuries but united by the aspect of female metaphysical longing for love, connects the novel with the symbolism of archetypes as defined by Carl Jung. The novel reveals that the modern woman is unable to perceive herself as dissociated from the past that archetypically inserts itself into the history of man-woman relations. Jung's assumption of Unus mundus (Latin for 'one world') holds the novel together. All three stories of The Witch and the Rain take place in a vertical timeline and stand out as fundamental, archetypical points that define female metaphysical longing. The literary critique Laimantas Jonušys noticed a paradox in this novel: "in the narrative of the story the men appear like gods and the women are submissive to them, but on the psychological level as a matter of fact important are only women, the men as personages for the author appear only as objects, as a point of measure. In this sense one can understand and the image of Christ - the author hardly could be blamed for profanation. Of course, the Christ created by Ivanauskaitè could appear as too human, doubtful, sad, but, it seem more provocative appears the image of Mary Magdalene, connected with the topic of this book - novel about the women's love, about bewitched, intoxicating, killing passion, about woman's sexuality" (Йонушис 1995: 15-16). In this novel woman is no just a "chalice of sin", deserving condemnation; she searches through love for her place in God and finds it. The Apostle Peter drives Mary Magdalene away from Christ: "You are a woman, and they are not worthy of living". According the Old Testament a libertine should be stoned to death. Jesus, however, washes her feet 
and says: "only love will make you free." Kubilius notices, that this is the novel's main idea, developed in several planes of the plot: woman's right to God's mercy is not less than of a priest or a monk who are also sinners. "The romantically fatal passion to the only man is accompanied here by light-minded intercourse with any stranger and lesbian caress, while the despair of a deserted woman - by nightmarish hallucinations and visions of mediaeval horrors a if transferred from Hieronymus Bosch's painting" (Kubilius 1997: 505)

Ivanauskaitè, in her writing, visual art, and life style, had broken the established rules of provincial culture based on the rural experience. She turned against the stream and, following the prose of Saulius Tomas Kondrotas and Ričardas Gavelis, created the path of Lithuanian literature "from the city". She turned the masculine sexually-free style of life expressed in Henry Miller's or Jack Kerouac's novels upside down and wrote Agnija's Magic in a similar style but from the woman's perspective. The novel Agnija's Magic (1995) sees a different trajectory of self-consciousness in the main female character Agnija. Unlike the women of The Witch and the Rain who die for love, Agnija has a more 'masculine' attitude that manifests itself in her choice of leading an active and erotically unrestrained lifestyle. Agnija is Amsterdambound as a photographer for her first Western exhibition. As a character, she is quite self-aware and ironic, endowing herself with a multitude of names; e.g. Agnija-the-Naïve, Agnija-the Cynic, Agnija-the Sexpot, Agnija-the Philosopher. On the cover of the first edition of the novel, a fragment of the Belgian surrealist Paul Delvaux's picture The Man in the Street (1940) was reproduced. The man in Delvaux's picture is very similar to Magritte's heroes with black official suits, but absent in the chosen fragment. Only women are left. In her poem dedicated to Delvaux, Ivanauskaite wrote: "The nudes, astonished by the whiteness of their naked bodies/In their glassy eyes/the luminary of madness/the moon is reflecting" (Ivanauskaitè 2007a: 101)

Ivanauskaite in the novels The Witch and the Rain and Agnija's Magic tried to grasp the natural essence of woman. One can find here many erotic scenes, oriental motifs, travelling adventures and wonderful pictorial scenes. Speedy rhythm of the life, strained mentality, longing to have and to give oneself up and at the same time - torturing question: is it possible to feel stable grounds of faith ? As Vytautas Rubavičius noticed, Ivanauskaitè in the novel Agnija's Magic "presented the most comprehensive literary phenomenology of a body; to discuss it with the Jungian metaphors of collective unconsciousness and the echo of Henry Miller's works would be very helpful" (Rubavičius 2007: 96).

This novel also reveals the author's interest in the mystical forces of the world. Violeta Kelertas interprets the novel as a case of postcolonial literature. She notices in it two incompatible desires: a sexual quest and an exalted spiritual state, combined with an attraction to the exotic, which express themselves in strange paradoxes: in trying out a new landscape, in trying out a new man, in experiencing a new country, Agnija attempts to experience a new belief system. These incompatibilities result in the novel's peculiar mixing of genres - the travelogue turns into an erotic text, after that - to a religious one, "non-traditional for the Western reader. For example, at the end of Agnija's Magic there is almost an appendix - a description of Buddhist theology and a list of rules to live by according to this faith. This is proselytizing, in a way. It invites followers. Back in Vilnius, Agnija has been interested in black magic and voodoo, but after traveling to India, she succumbs to the influence of Buddhism" (Kelertas 2006: 453). Finally, Agnija's Magic differs from the other three pre-Tibetan novels due to its self-liberating nature. It has no apocalyptic finale of self-destruction; noone dies or commits suicides. In this novel Ivanauskaitè begins drawing the symbols of her travels into her literary space. On the other hand, the horrors from Hieronymus Bosch's painting are deep inside Agnija's consciousness. She compared her impression of Amsterdam with visions from a Boschian picture: "The Boschian Hell, whose horrible wheels are turning in the narrow street of the old medieval town, full of flowers, the presentiments of death, music, trivial laughter and desire" (Ivanauskaitè 2006a: 14).

Even if Ivanauskaite had stopped writing, as she said she would to fully embrace Buddhism, her two collections of short stories (The Year of the Lilies of the Valley, How to Raise One's Own Fear) and her four novels (The Children of the Moon, The Gardens of Hell, The Witch and the Rain, Agnija's Magic) would have already made their mark on Lithuanian literature as modern classics of urban literature that range from the surreal to the existential.

\section{The 'Tibetan' Works: A Journey towards Oneself}

In 1994 Ivanauskaite took her first trip to India and studied Budhism at Dharamsala, gaining the impetus to start a new page in her literary work. These works covers Ivanauskaitè's creation between 1996 and 2000: three essay books (Tibet in Exile,1996; A Journey to Shambala, 1997; The Lost Promised Land,1999), one novel (Gone with the Dreams, 2000) and the collection of poems The Dance in the Desert (2004).

One can propose several conceptual explanations for Ivanauskaitè's phenomenon of travel: situational-social, 
psychological, fate-related, ecumenical, and anthropological-genetic. We think that the most accurate is the culturalspiritual explanation which emphasizes the journey as a certain quest for spiritual experience and the opportunity to construct oneself in the face of otherness. The otherness enchants the writer's imagination with the opportunity for manifold - spiritual, existential and even physical - renewal.

Ivanauskaitè's book Tibet in Exile (1996) the first book of The Tibetan Mandala, reflects the author's desire to understand the concept symbolism of a foreign culture and to erase the habit of creative writing. To a large extent it reminds the reader of a beginner's guide to Buddhism and provides information on the various aspects of Tibetan culture, religion and history. However, the suppressed creative spiritual intensity of the writer breaks through as reflective essayist prose. As notices Howard Jarvis "Until the first of these, absolutely no books on Tibet had been available in the Lithuanian language. A collection of traveler's tales and in sights into religion, political situation and everyday reality of Tibetans living in exile in Northern India, Tibet in Exile delves into the soul of one of the world's most profoundly spiritual societies. It even has a personal foreword by the Dalai Lama, whom Ivanauskaite has met on several occasions. Lithuanian readers seem to relate well with the subject of Tibet. The idea of a distant mountain kingdom chimes in with the romantic ideals of the Lithuanian character, while its fate of invasion and exile connects directly with Lithuanian memories of occupation and harsh, often religious persecution "(Jarvis 2005: 24-25).

In the second book from the journey The Journey to Shambhala, (1997) this reflective essayist prose reaches its top form. In this book the experiences of the narrator can be viewed from several different angles. On the one hand, she is a proactive person who travels, changes her location, and makes unexpected decisions. On the other hand, she is a seeker who is still searching for the secret codes of this culture and attempts to penetrate its depth both in theory and in practice, even if it puts her at risk. An erudite, the writer wants to become an expert of her chosen path, she studies the plentiful sources that explain and interpret the tradition in question. Third, she is who she is - an individual, a psychological human being. Her subconscious works like an engine and sends her unexpected, at times traumatizing, impressions and signals. Fourth, she is a writer, who not only describes the characteristics of this culture, but also how it affects the seeker herself. Fifth, she constantly withdraws and sees reality from the sidelines, as she would take in a visual art or, more accurately, a film. In this way she activates her thoughts and perceives the situation and herself in a greater depth and from a different angle than it would be possible from the confines of everyday domestic life. All these interwoven aspects and the tensions that arise from their connections are presented in an intriguing and challenging narrative which seems to be written by the author herself, or by the journey as a unique fragment of life. In reality, the narrator wants to be objective, to see the world without the veil of illusion and understand everything the way it is; she is aware of all other possible variations and dispersions of the ego. In a way, The Journey to Shambhala is the most convincing of the author's works. As notices Regina Rudaityte, "Symbolically, the writer's journey to Shambhala becomes an inward journey, a sacred journey to one's own hidden self in search of spirituality with the aim of changing oneself and assuming a different, according to Ivanauskaitè, a superior identity. This change presupposes an absolute refusal from egotism, the annihilation of one's ego and the "obliteration of personal history" as a means of attaining happiness and bliss, nirvana "So what if my ego quizzically whispers to me that I used to like French cooking or Chinese delicacies, vintage red wine, and that I used to hobnob with refined aesthetes? But then and there I felt a void, I felt that something was always missing, while here and now, cutting the bird-like toenails from Lama's unwashed feet I am feeling happy. Maybe this is the bliss which only the obliteration of personal history can bring about. Here nobody is interested either in my native country or city, language, profession, social position, either in my family, age or my real name. I am simply Nobody having come from the Nowhere country where time should probably be named Never" (Rudaityte 2009: 119).

In this book Ivanauskaite describes many of her personal experiments with Buddhist spiritual practice and insights, both inspiring and tormenting. She felt intense inner conflict between her Western background and her very new experiences of living and being instructed by lamas in Ladakh and Nepal. As recollected Jarvis: "even when it is time to leave, the conflict between physical and spiritual is still there: "Upon leaving Ladakh, I feel as if I have to be separated from a person whom I love madly. I want to say farewell by making some tangible gesture, so I can feel a physical closeness. But what I embrace, clasp to my breast, kiss - the mountains, the deserts, the air, the light, the silence? "(Jarvis 2005: 25).

A reference guide to authors and their work Baltic Writers: Estonia, Latvia, Lithuania provides an information, that: "during the period of the National Revival, Ivanauskaite turned to Christianity, but later became a Buddhist, and in 1994, on the eve of a journey to India, she declared she would stop writing fiction, as it was not compatible with Buddhist practice. However, at the end of her life she returned both to her literary work, and to Christianity' (Daugirdaite 2009: 110).

First of all, Ivanauskaite returned to literary writing not at the end of her life, but at the very beginning of her first 
journey; during her travels she was sending essays that were published in the newspaper Lietuvos Rytas. While traveling she also finished her pre-Tibetan book Agnija's Magic in 1995 and in 1996 she published her essays in a book Tibet in Exile. The Dalai Lama wrote the preface for this book. During her travels she also published her greatest collection of essays, Journey to Shambala (1997), based on her experience traveling in India, and the third book from the trilogy The Lost Promised Land (1999) about her trip to Tibet.. Even her later novel Gone with the Dreams (2000) was based on her traveling experience, as well as her later published collection of poetry The Dance in the Desert (2004). In the book, the author reveals the various possible trajectories of metaphysical longing by way of short poetic meditations. These miniatures are included in the book The Lost Promised Land as ostensible manuscripts of Pema Dečen.. The author also plays the role of literary critic and interpreter by telling the reader what she thinks of her own poetry. Rudaityte notices that when traveling, "she $\langle\ldots\rangle$ questions the poststructuralist view of the world created by discourse which, however, according to Ivanauskaitè, 'is not the sole reality but only a narrow subjective space created by ourselves."' (Rudaitytè 2009: 119). Of course she questions, but on the other hand, it is not very difficult to notice that Ivanauskaite never stopped creating this discourse regardless of her declarations.

Secondly, the provided research revealed that Ivanauskaite never exchanged Christianity for Buddhism or the other way round. Though during the period of the fight for national independence she was christened by Monsignor Kazimieras Vasiliauskas, Ivanauskaite was not a zealous church visitor. In video material she confesses that she experienced transcendence somewhere else, for example in the forest, because in the church it used to disappear suddenly. She read the Bible, the Koran and the basics of the Kabbalah and explored the tradition of Buddhism. In all religions she sought out the mystic intrigue of the secret signs and numinosum. On the one hand, the writer was intrigued by 'witchery' and magic while on the other hand, her search was fuelled by a strong longing for the sacred. She could discern some signs of sanctity in pagan culture (the culture of stones, for example). The two-fold tension between believing and not believing is also reflected in the diary Overtime, in which visions and a mystic experience of closeness with God are replaced with doubts and scepticism. The fundamental intrigue of the phenomenon of Ivanauskaite is the fact that she never fully identified herself with any world-view or conception and, regardless of or because of this, felt a constant metaphysical longing for uninterested love, sanctity, absolute gentleness, unity, and perfection. In search for numinosum Jung as well as Thomas Merton and Master Eckhart were her spiritual leaders.

\section{The 'Post-Tibetan' Works: Social Motifs}

When Ivanauskaitè returned to Lithuania after her travels, she experienced a deep feeling of loss. "I suffer from an overwhelming feeling of nostalgia", she says. "I can't even watch images of Tibet or the Himalayas on television, when my friends call to tell me they're on. My heart would be broken", recollects Jarvis (Jarvis 2005: 24). But she never abandoned her work and continued writing. During the post-Tibetan period (2000-2007), she published a collection of essays based on her trips to other countries, The Alchemy of Travels, and the interview book The Gentle Interrogations, (2005), as well as two more novels: Placebo (2003) and The Fortress of Sleeping Butterflies (2005), a fairy-tale for children How Marsis Searched for Happiness on Earth, succeeded to finish her last poetry collection Ode to Joy and left unfinished her diary Overtime, published by her mother Ingrida Korsakaite after the writer's death, without any mention of her traveling experience in India and Tibet.

In the collection of essays The Alchemy of Travels (2003) she proves her essay-writing skills yet again. She uses irony, self-irony, wit and laconic speech; she discusses issues in a seemingly care-free, playful way, but manages to reach their roots. Following Jung's example, she calls this writing method 'synchronicity', but it can also be seen as a certain phenomenology.

The first post-Tibetan novel Placebo (2003) meats the reader as a detective story: the main heroine is killed or kills herself on the first page. However this does not preclude her from telling stories and making comments from beyond the grave, from a peculiar intermediate state of death, by flying and looking around. She is surprised by her own death, asking questions: "how long had it been already? A day? A week? A month? A year? A decade? "(Ivanauskaitè 2004:11). On the other hand this book, as noticed Gintaras Beresnevičius, is almost a documentary historical book in which one recognizes all the scandals, misunderstandings, pleasures and enjoyments, follies and realities of the Lithuanian in the beginning of 21-irst century. Novel Placebo looks like a literary parody of consumerism. The tone of the narrative is ironic. Five different planes are interwoven in the novel. The first is the afterlife plane of the fortune-teller Julija. The second plane of realistic everyday life is split into two parts: the introspective musings of the characters, which, although characteristic of Ivanauskaitè, is less apparent in this novel than in her pre-Tibetan works, and the social space, which is an entirely new element. There is also the cosmic reality of reincarnations, thoughts, and experiences of the cat Bastètè, 
as if from the novel Gone with the Dreams. Finally, the fifth plane is the dimension of the Centre or that of the creators of the Placebo. In this novel Placebo is a substitute for reality. The underlying intellectual intrigue of the novel is that we exist not in reality but in its substitute the qualities of which are created, changed or otherwise controlled by some more powerful force, the so-called Centre. Julija "was lured to Placebo five years ago not by an insatiable thirst for money, but by a passionate with to do battle with the wealthy, self-satisfied and satiated. An antipathy towards politicians and anarchist beliefs meant any form of government was inherently bad. Julija confirmed to herself that she had an inborn, perhaps karmic, genetic predisposition toward those types who are perched at the top of he social pyramid, deciding the fate of the people and country. Politics always (except for the brief "Singing Revolution" interlude) seemed to her as the same old dreadful and cynical farce" (Ivanauskaitè 2004e: 12). Here Ivanauskaite once again approaches the concept of the world-reformer, conceived by Ričardas Gavelis in his novel Vilniaus džiazas (Jazz of Vilnius). As notices Gintaras Beresnevičius "It is a post-modern novel with an underlying metaphysical implications; however, it is also a continuation of perhaps the last 15 years of Lithuanian novels, because here I can see both Glisono kilpa and Tüla, (novels by Jurgis Kunčinas - J.B.) and, of course Vilniaus pokeris with "Them" by Ričardas Gavelis" (Beresnevičius 2004: 9).

In 2005 Ivanauskaite published her second and last post-Tibetan novel, The Fortress of Sleeping Butterflies (2005) in which she intertwines some major themes: human trafficking, social help and the age of the apocalypse. The novel breaks down into two narrative planes, the internal and the external. The internal plane is moderated by the introspective thoughts of the main character Monika. The external narrative is centred upon her social project of resocialization of former prostitutes. Trafficking in women ("butterflies" as they are called by country folk) is described in the novel without any didactic shade, thought with sympathy and empathy, questioning the role of the "victim". As noticed Giedre Kazlauskaite "an important social (as well as existential) theme dictates the free, evangelically humane declaration of the authors positions, to turn back and look at man in dirt and trouble, misery, and the senselessness of life" (Kazlauskaitè 2006: 86).

This narrative was used by Lithuanian film director Algimantas Puipa, who directed a film of the same name The Fortress of Sleeping Butterflies (2012) in which the internal plane was suspended and Apocalypse disappeared. Meanwhile, the apocalyptic atmosphere of this internal plane in Ivanauskaite's novel brings it close to the archetypical symbols in the film Melancholia (2011) directed by Lars von Trier. The main protagonist Monika constantly feels the pulsation of Murderer Star. Unlike her last two novels, Gone with the Dreams and Placebo, this novel is devoid of the afterlife and cosmic dimensions. But cosmos have turned into the threat of the Apocalypse. The primary reality unrolls in Monika's consciousness. Monika reflects: "Galaxies will start decomposing, and the degenerated stars will be bumping into each other, while their corpses and their broken pieces will be falling into black holes. Scientists make predictions that these developments will only start in approximately sixty billion years from now. But maybe scientists made an in significant error, and the Degradation era is starting tonight. And maybe the Suicide Star that I can observe so clearly is the first herald of these Apocalyptic developments" (Ivanauskaite 2011b: 69). These are the moods and the possible thought of Justine from Melancholy by von Trier. Ivanauskaite wrote it in 2005. Trier created the movie in 2011. It is obvious that the novel written by Ivanauskaite he never red. Ivanauskaite if were alive would have called this parallels following Carl G.Jung as sinchronicity. As notices Kazlauskaitè, reflecting upon Monika's inner states in the novel The Fortress of Sleeping Butterflies "the symptoms of a woman suffering from depression are exact and characteristic, the psychological nuances are accurate (Kazlauskaitè 2006: 87).

Ivanauskaitè's last book Ode to Joy (2007), coincided with the author's death - it appeared the day she died. It is a collection of poems written over a significant period of time, and only seven of those poems are new. In a way, it closes a cycle of her creation, as Ivanauskaite began her creative path with poems published in the magazine Moksleivis when she was at school. Having returned to poetry, the writer felt the fragile nature of a poem and made an effort not to violate it: she did not overdo it or push it too far. Her poems are of moderate length; they are neither overburdened with metaphors nor pretentious. Had she not exchanged poetry for prose, and continued writing poems as she did at school, Ivanauskaite might have made her mark in our cultural context as a Lithuanian Wisława Szymborska: the poetry of both is moderate, ironic, intellectual, and capable of describing fundamental issues (or creating existential symbols) in a concise form. Ivanauskaite simply did not write enough poetry. In her poem Morning. Another Incarnation she wrote: "Having risen from the dead /I hang around the seashore, /gather/pocketfuls of seashells/and listen, oh I listen/to the humming of the sea waves/until l've forgotten/the drumming of earth/onto my coffin lid" (Ivanauskaitè 2010: 2). The translator of her poems into English Paul Perry reflects: "What I feel when I read her work is the presence of a compassionate and longing voice, one which has a seductive intimacy to it, a voice which will tell the hard truths, but which has an ironic twist to it also. $<. . .>$ In it, she faces her own mortality with a steadfast stare and a brave wit and irony " (Perry 2010: xi-xii).

However, the format of a poem was too constricting for her, as was that of the novella. Considering the scale of her 
passion for life, the small genres could only be temporary endeavors. They were too delicate. Thus Ivanauskaite published only two books of poetry, two of short stories, one collection of interviews, and two books for children. Yet she left seven novels, only the first two of which were a little shorter. The other five are books of impressive length. Vytautas Kubilius was right when he said that Ivanauskaite was a writer of fervent spiritual tension.

In one of her interviews she formulated the two-sidedness of their creation: "Writing and painting are two different things. Writing is a very exhausting and tormenting activity: while writing you constantly feel tension, you feel how your unconsciousness is boiling, working. During the nights when I am writing a novel I see texts coming to me in my dreams. A terribly tiresome and exhausting process: all day you are writing and afterwards all night you are further laying out the words. Pictures for me are pure meditation. After meditation you quietly fall asleep. All day you are painting, but when your work is finished - that's all. The burden falls off your shoulders and nothing else is tormenting you (Baranova 2014: 194).

\section{References}

Baranova, J. (2014) Jurgos Ivanauskaitès fenomenas: tarp siurrealizmo ir egzistencializmo (The Phenomenon of Jurga Ivanauskaité: Between Surrealism and Existentialism) Vilnius: Tyto alba. In Lithuanian.

Beresnevičius, G. (2004). The Dawn of Ersatz Civilisation. The Vilnius Review. New Writing from Lithuania, no.15, pp. 7-10.

Deleuze, G.,Guattari, F. (1986) Kafka: Towards a Minor Literature. Mineapolis, London: University of Minnesota Press.

Deleuze, G. (1995) Negotiations. New York etc.: Columbia University Press.

Ivanauskaité, J. (1985) Pakalnučiu metai (The Year of the Lilies of the Valley): [short stories].Vilnius:Vaga. In Lithuanian.

Ivanauskaitè, J. (1988) Mènulio vaikai (The Children of the Moon): [novel]. Vilnius: Vaga. In Lithuanian,

Ivanauskaitè, J. (1989) Kaip užsiauginti baimę (How to Raise One's Own Fear): [short stories and novellas]. Vilnius: Vaga. In Lithuanian.

Ivanauskaitè, J. (1991) Stebuklinga spanguolè (The Miraculous Cranberry): [fairy tale]. Vilnius: Vyturys. In Lithuanian.

Ivanauskaité, J. (1992) Pragaro sodai (The Gardens of Hell): [novel]. Kaunas: Nemunas. In Lithuanian.

Ivanauskaité, J. (1993) Ragana ir lietus (The Witch and the Rain): [novel]. Vilnius: Vaga,. In Lithuanian.

Ivanauskaitè, J.(1995) Agnijos magija (Agnija's Magic): [novel]. Vilnius: Vaga,. In Lithuanian.

Ivanauskaitè, J.(1996) Ištremtas Tibetas (Tibet in Exile): [essays]. Vilnius: Tyto alba,.

Ivanauskaité, J. (1997a) Kelionè i Šambala (The Journey to Shambhala): [essays]. Vilnius: Tyto alba. In Lithuanian.

Ivanauskaitè, J (1997b) Nõid ja vihm, (The Witch and the Rain ). Tallinn: Olion. Translated into Estonian. by Mihkel Loodus.

Ivanauskaitè, J. (1997c) Mikor jön el Godot? Polisz, nr.29, pp.40-44. Translated into Hungarian by Bàn Péter.

Ivanauskaitè J. (1997d) The Day That Never Happened. In Lithuania in Her Own Words. An Anthology of Contemporary Lithuanian Writing. Ed.Laima Sruoginis. Vilnius: Tyto alba, pp.193-201. Translated into Lithuanian by Laima Sruoginis.

Ivanauskaitè, J (1998) Celojums uz Šambalu (The Journey to Shambhala). Rĩgā: Jumava, , Translated. to Latvian by Talrids Rullis.

Ivanauskaitè, J. (1999a) Prarasta pažadètoji žemė (The Lost Promised Land): [essays on Tibet].Vilnius: Tyto alba. In Lithuanian.

Ivanauskaitè, J. (1999b) Agnijas magija (Agnija's Magic). Rīga: Avots. Translated into Latvian by Talrids Rullis.

Ivanauskaitè, J. (2000a) Sapnu nublokšti (Gone with the Dreams): [novel]. Vilnius: Tyto alba. In Lithuanian.

Ivanauskaitè, J (2000b) Zaudētā Apsolitīā zeme (The Lost Promised Land). Rĩga: Jumava. Translated. into Latvian by Talrids Rullis.

Ivanauskaité, J.(2001a) Trimdā aizdzitāa Tibeta (The Tibetan Mandala), Rĩga: Jumava. Translated into Latvian by Talrids Rullis.

Ivanauskaitè, J. (2001b) Czarownica i deszcz (The Witch and the Rain): (excerpt from novel). In Sen Mendoga. Antologija literatury litewskiej lat dziewiecdziesiatych. Warszawa: Ksiązka i wiedza, pp.257-272. Translated. into Polish by Alicje Rybalko.

Ivanauskaité, J. (2002a) Ragana ir lietus (The Witch and the Rain): [novel]. Vilnius: Tyto alba. In Lithuanian.

Ivanauskaitè, J. (2002b) A Few Thoughts on Spiritual Life Since Lithuanian Independence. A Personal Essay. In: The Earth Remains: An Anthology of Contemporary Lithuanian Prose.Vilnius: Tyto Alba, pp. 308-312. Translated into English by Laima Sruoginis.

Ivanauskaitè, J. (2002c) Gone with the Dreams (excerpt from novel). In: The Earth Remains: An Anthology of Contemporary Lithuanian Prose. Vilnius: Tyto Alba, pp.313-331. Translated into English by Laima Sruoginis.

Ivanauskaitè, J (2002d) Die Regenhexe (The Witch and the Rain). Deutsche Erstausg, München: Deutscher Taschenbuch Verl. Translated. into German by Markus Roduner.

Ivanauskaitè, J (2002e) Das haus ausserhalb der stadt. Meldung über Gespluster. Erzählungen aus Litauen. Salzburg: Otto Müller verlag, pp. 176-182.

Ivanauskaité, J. (2003a) Pakalnučiu metai (The Year of the Lilies of the Valley): [short stories].Vilnius: Tyto alba. In Lithuanian.

Ivanauskaitè, J. (2003b) Kelioniy alchemija (The Alchemy of Travels): [essays]. Vilnius: Tyto alba. In Lithuanian.

Ivanauskaité J. (2003c) L'année des muguets. In Des ames dans le brouillard. Anthologie de nouvelles lituaniennes contemporaines. Presses universitaires de Caen, pp.155-167. Translated into French by Ugnè Karvelis.

Ivanauskaitè, J.(2003d) Placebas (Placebo): [novel]. Vilnius: Tyto alba. In Lithuanian.

Ivanauskaitè, J (2003e) Vještica i kiša (The Witch and the Rain). Zagreb: Profil international. Translated into Croatian by Loreta Vasilj.

Ivanauskaité, J. (2004a) Mėnulio vaikai (The Children of the Moon): [novel]. Vilnius: Tyto alba. In Lithuanian

Ivanauskaitè, J. (2004b) Kaip Marsis žemèje laimès ieškojo (How Marsis Searched for Happiness on Earth): [fairy-tale]. Vilnius: Tyto alba. In Lithuanian.

Ivanauskaitė, J. (2004c) Šokis dykumoje (The Dance in the Desert): [poems]. Vilnius: Tyto alba. In Lithuanian. 
Ivanauskaitè, J. (2004d) Tibeto mandala (The Tibetan Mandala): [trilogy]. Vilnius: Tyto alba. In Lithuanian.

Ivanauskaitè, J.(2004e) Placebo (excerpt from novel). The Vilnius Review. New Writing from Lithuania, spring, no.15, pp.11-19. Translated into English by Darius Ross.

Ivanauskaitè J. (2004f) Slik. Posldni vlak Ivanje. In Brauko Mirjana. Antologija litovske. Kratke price. Zagreb: Biblioteka živi jezici, pp. 166-191. In Croatian.

Ivanauskaitè, J. (2005a) Miegančiu drugeliu tvirtovè (The Fortress of Sleeping Butterflies): [novel]. Vilnius: Tyto alba. In Lithuanian. Ivanauskaitè, J (2005b) Placebo. München: Deutscher Taschenbuch Verlag. Translated into German by Markus Roduner.

Ivanauskaitè, J (2005c) Häxan och regent, (The Witch and the Rain). Stockholm: Tranan. Translated into Swedish by Jonas Öhman.

Ivanauskaitè, J (2005d) Švelnūs tardymai (The Gentle Interrogations). Vilnius : Tyto alba. In Lithuanian.

Ivanauskaitè, J.(2006a) Agnijos magija (Agnija's Magic): [novel]. Vilnius: Tyto alba. In Lithuanian.

Ivanauskaitè, J (2006b) Sapñiem līdzi: [Gone with the Dreams]. Rīga, Dienas Grāmata, . Translated into Latvian by Talrids Rullis.

Ivanauskaitè, J. (2006c) Čarodějnice a déšt (The Witch and the Rain). Praha: Mezera. Translated into Czech by Gabriela Šroubková.

Ivanauskaitè, J.(2007a) Odè džiaugsmui (Ode to Joy): [poems]. Vilnius: Tyto alba In Lithuanian. .

Ivanauskaitè, J.(2007b) Viršvalandžiai (Overtime): [essays]. Vilnius: Tyto alba. In Lithuanian.

Ivanauskaitè, J.(2007c) Nežaiskite su mènuliu! (Do Not Play with a Moon!): [plays]. Vilnius: Tyto alba. In Lithuanian.

Ivanauskaitè, J. (2008) Citanje proznog štiva. In Forum. Zagreb. Travanj-lipanj, 4-6, pp.486-493. In Croatian.

Ivanauskaitè, J. (2009) Kaip užsiauginti baimę (How to Raise One's Own Fear): [short stories and novellas]. Vilnius: Tyto alba. In Lithuanian. Ivanauskaitè, J. (2010a) Pragaro sodai (The Gardens of Hell): [novel]. Vilnius: Tyto alba. In Lithuanian.

Ivanauskaitè, J.(2010b) 108 Moons. The Selected Poems of Jurga Ivanauskaitè, Dublin: The Workshop Press. Translated into English by Paul Perry and Rūta Suchodolskytè.

Ivanauskaitè, J.(2010c) In aereo. Alla Fiera del libro. Avventura notturna. Circolo vizioso. In Poetare e pensare in forma di parole. Mappa della poesia lituana del terzo Novocento. Poeti degli anni sessanta. numero secondo, aprile, magiio, giugno, pp. 172-189. A cura di Pietro U.Dini.

Ivanauskaitè, J.(2011a) Angelo rūbas (The Angel's Dress). Vilnius: Tyto alba. In Lithuanian.

Ivanauskaitè, J.(2011b) The Fortress of Sleeping Butterflies (excerpt from novel). In No Men, No Cry. Contemporary Lithuanian Women's Prose. Chicago: International Cultural Programme Centre, pp. 63-75. Translated into English by Milda Dyke.

Ivanauskaitè, J. (2013a) Year of the Lily of the Valley. In The Dedalus Book of Lithuanian Literature. Ed.by A.Samalavičius. London: Dedalus, pp.146- 157.

Ivanauskaitè, J.(1994, 2013b) Ragana un lietus, (The Witch and the Rain). Rīga: Preses names. Translated. into Latvian by Talrids Rullis.. Ivanauskaitè, J. (2013c) La strega e la pioggia (The Witch and the Rain). Novi Ligure: Edizioni Joker.Translated into Italian by Pietro U. Dini. Ivanauskaitè, J. (2014a) Stebuklinga spanguolè (The Miraculous Cranberry): [fairy tale]. Vilnius: Tyto alba. In Lithuanian.

Ivanauskaitè, J. (2014b) Čarovnica i dež (The Witch and the Rain). Maribor: Pivec . Translated into Slovenian by Klemen Pisk.

Иванаускайте, Ю. (2002f) Путешествие в Шамбалу (The Journey to Shambhala) Киев: София; Москва: ИД Гелиос. Translated. into Russian by Natalija Vorobjova. In Russian.

Иванаускайте Ю. (1983) Год ландышей. Литва Литературная, no.5, cc. 76-85. Перевод Анны Герасимовой. In Russian.

Иванаускайте, Ю. (1992) Иванова ночь. Вильнюс.Vilnius, no.5-6, 100-107. Перевод Аллы Асовской. In Russian.

Иванаускайте, Ю. (1995) Ведьма и дождь. Вильнюс.Vilnius, no.1-2, cc. 17-67. Перевод Екатерины Йонайтене. In Russian.

Иванаускайте, Ю. (1995) Ведьма и дождь. Вильнюс.Vilnius, no.3-4, cc. 16-90. Перевод Екатерины Йонайтене. In Russian.

Иванаускайте, Ю. (1995) Ведьма и дождь. Вильнюс.Vilnius, no.5-6, cc. 22-93. Перевод Екатерины Йонайтене. In Russian.

Jarvis, H. (2000). A Colourful Bird in a Pale Land : why Jurga Ivanauskaitè's Books are Crying out for Translation. Central Europe Review, vol 2, http://www.ce-review.org/00/27/jarvis27.html. Retrieved 2015-03-10.,

Jarvis, H.(2005) Drawn to the Mystical World. Vilnius Now! June, pp.24-25.

Daugirdaitè, S.(2009) Ivanauskaite Jurga. In Baltic Writers. Estonia, Latvia, Lithuania. A Reference Guide to Authors and Their Works. Vilnius: Institute of Lithuanian literature and folklore, pp.109-110.

Kazlauskaitė G. (2006) Let Sleeping Butterflies Lie. The Vilnius Review. New Writings from Lithuania. Spring, no.19, pp. 86-88.

Mažeikis, G. (2012) Išlaisvinantis paribiu sąmoningumas Jurgos Ivanauskaitės ir Ričardo Gavelio romanuose. Inter-studia humanitatis, no. 13. pp.45-66.

Kelertas, V. (2006) Foot-Loose and Fancy-Free The Postcolonial Lithuanian Encounters Europe. In Baltic Postcolonialism. Ed.V.Kelertas. Amsterdam and New York: Rodopi, pp. 451-459.

Kubilius (1997) The Integration of Split Literature. In Lithuanian Literature. Vilnius: Vaga., pp. 477-508.

Urbonaitè, A (2015) Mano didžioji nuodèmè, žurnalistika (My Greatest Sin, Journalism) Vilnius: Alma littera.

Meuris, J. (1994) René Magritte 1898 - 1967. Koln: Benedikt Taschen.

Radvilavičiūtè, G. (2007) Šiaurès vasara. Literatūra - tarp fakto ir išmonès. (The North Summer. Literature - Between Fact and Wit) Tarptautinis šiuolaikinès literatūros forumas. Programa. 2007 rugpjiūčio 24-26. Vilnius/ Jurbarkas.

Radvilavičiūtè, G. (2008) Šiaurès vasara. Rašytojas ir maištas. (The North Summer. Writer and Revolt) Tarptautinis šiuolaikinès literatūros forumas. Programa. 2008 birželio 12-15. Vilnius/ Jurbarkas.

Rubavičius V. (2007) Kaip sugrižti i kūną?(How to Return to One‘s Body? ) In Rubavičius, V. Neivardijamos laisvès ženklas. Vilnius: LRSL, pp. 295-300.

Rudaitytè, R. (2009) In Search of The Self: Jurga Ivanauskaite‘s Journey to Shambhala. Literatūra. 2009, no.51 (4), pp. 114-120.

Йонушис Л (1995) Самобытный роман о женской страсти. Вильнюс.Vilnius, no. 1-2, cc. 14-16. In Russian. 